\title{
Synthesis of Simplified Hybrid Inhibitors of Type 1 17 $\beta$-Hydroxysteroid Dehydrogenase via the Cross-Metathesis and the Sonogashira Coupling Reactions
}

\author{
Marie Bérubé and Donald Poirier \\ Medicinal Chemistry Division, Oncology and Molecular Endocrinology Research Center \\ and Université Laval, Centre Hospitalier Universitaire de Québec (CHUQ), Pavillon \\ CHUL, 2705 Laurier Boulevard, Quebec, Qc, G1V 4G2, Canada
}

\section{Supporting Information}

Chemical Synthesis of 2a-15

General methods

Reagents were obtained from Sigma-Aldrich Canada Co. (Oakville, ON, Canada) except 2,6-diiodo-4-nitroaniline purchased from Acros Organics (distributed by Fischer Scientific, Montreal, Qc, Canada) and tricyclohexylphosphine [1,3-bis(2,4,6trimethylphenyl)-4,5-dihydroimidazol-2-ylidene] [benzylidine] ruthenium(IV)dichloride purchased from Strem Chemicals (Newburybort, MA, USA). Usual solvents were obtained from Fisher Scientific and VWR (Ville Mont-Royal, Qc, Canada) and were used as received. Anhydrous solvents were purchased from Aldrich and VWR in SureSeal bottles, which were conserved under positive argon pressure. Tetrahydrofuran (THF) was distilled from sodium/benzophenone under argon. All anhydrous reactions were performed in oven-dried glassware under positive argon pressure. Thin-layer chromatography (TLC) was performed on $0.25-\mathrm{mm}$ silica gel $60 \mathrm{~F}_{254}$ plates (Whatman, Maidstone, England), and compounds were visualized by exposure to UV light (254 nM) and/or with a solution of ammonium molybdate/sulphuric acid/water (with heating). Flash chromatography was performed on Silicycle 60 (Quebec, Qc, Canada) 230-400 mesh silica gel. Infrared (IR) spectra were obtained from a thin film of the solubilized compound on $\mathrm{NaCl}$ pellets (usually in $\mathrm{CH}_{2} \mathrm{Cl}_{2}$ ). They were recorded on a Perkin-Elmer series 1600 FT-IR spectrometer (Norwalk, CT, USA); only significant bands are reported (in $\mathrm{cm}^{-1}$ ). ${ }^{1} \mathrm{H}$ and ${ }^{13} \mathrm{C}$ NMR spectra were recorded with a Bruker AC/F 300 spectrometer (Billerica, MA, USA) at 300 and $75 \mathrm{MHz}$, respectively, and a Bruker AVANCE 400 spectrometer at $400\left({ }^{1} \mathrm{H}\right)$ and $100\left({ }^{13} \mathrm{C}\right) \mathrm{MHz}$. The chemical shifts $(\delta)$ are expressed in ppm and referenced to chloroform (7.26 and $77.00 \mathrm{ppm})$ or acetone (2.07 and 206.00 ppm) for ${ }^{1} \mathrm{H}$ and ${ }^{13} \mathrm{C}$ respectively. Duplication of NMR signals was generally recorded for THP derivatives (presence of two stereoisomers). Low-resolution mass spectra (LRMS) were recorded with an LCQ Finnigan apparatus (San Jose, CA, USA) equipped with an atmospheric pressure chemical ionisation (APCI) source on positive or negative mode. 
Synthesis of 3,5-diiodonitrobenzene $(\mathbf{9})^{1}$

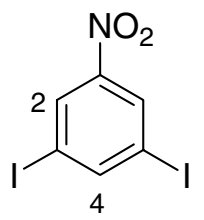

To concentrated $\mathrm{H}_{2} \mathrm{SO}_{4}(96 \%, 15 \mathrm{~mL})$ cooled at $0^{\circ} \mathrm{C}$ was added in small portions 2,6-diiodo-4-nitroaniline ( $3.9 \mathrm{~g}, 10 \mathrm{mmol}$ ). After complete dissolution of the aniline, $\mathrm{NaNO}_{2}(1.5 \mathrm{~g}, 22 \mathrm{mmol})$ was added at $0^{\circ} \mathrm{C}$ and stirred for $2 \mathrm{~h}$ at this temperature. Then, the viscous solution was poured into ice $(100 \mathrm{~g})$ and any solid material was filtered off. The yellow filtrate was carefully poured into a refluxed solution of $\mathrm{CuSO}_{4} .5 \mathrm{H}_{2} \mathrm{O}(160 \mathrm{mg}, 1 \mathrm{mmol})$ in $\mathrm{EtOH}(200 \mathrm{~mL})$ and stirred for $2 \mathrm{~h}$ to reduce the diazonium salt. After cooling to room temperature, solid 3,5-diiodonitrobenzene separated. The product was filtered off and washed with water until neutral. The product was recrystallized from $\mathrm{EtOH}$ to give $2.48 \mathrm{~g}$ (66\% yield) of fine brown needles. IR (film) $v=1522$ and $1337\left(\mathrm{~N}=\mathrm{O}, \mathrm{NO}_{2}\right) ;{ }^{1} \mathrm{H}$ NMR $\left(400 \mathrm{MHz}, \mathrm{CDCl}_{3}\right) \delta=$ 8.37 (t, $J=1.4 \mathrm{~Hz}, 1 \mathrm{H}, 4-\mathrm{CH}), 8.52(\mathrm{~d}, J=1.4 \mathrm{~Hz}, 2 \mathrm{H}, 2-\mathrm{CH}) ;{ }^{13} \mathrm{C}$ NMR $(75 \mathrm{MHz}$, $\left.\mathrm{CDCl}_{3}\right) \delta=94.1(2 \mathrm{x}), 131.7(2 \mathrm{x}), 148.4,151.0$; LRMS: calculated for $\mathrm{C}_{6} \mathrm{H}_{3} \mathrm{I}_{2} \mathrm{NO}_{2}$ $[\mathrm{M}]^{-} 374.8$, found $374.9 \mathrm{~m} / \mathrm{z}$.

$\underline{\text { Synthesis of N-tert-butoxycarbonyl-3,5-diiodoaniline (11) }}$

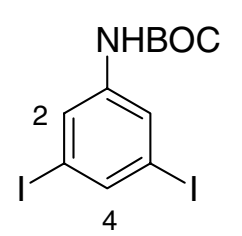

To a suspension of $9(7.15 \mathrm{~g}, 19 \mathrm{mmol})$ in anhydrous EtOH $(75 \mathrm{~mL})$ under argon was added $\mathrm{SnCl}_{2} \cdot 2 \mathrm{H}_{2} \mathrm{O}(21.6 \mathrm{~g}, 96 \mathrm{mmol})$. This mixture was brought to boil and a solution of $\mathrm{NaBH}_{4}(361 \mathrm{mg}, 9.5 \mathrm{mmol})$ in $\mathrm{EtOH}(40 \mathrm{~mL})$ was added dropwise. The reaction mixture was stirred at reflux for $20 \mathrm{~min}$. After the reaction was cooled down to $0^{\circ} \mathrm{C}$, water $(60 \mathrm{~mL})$ was added and the mixture was neutralized with $\mathrm{NaOH}(2.5 \mathrm{M}$ in $\mathrm{H}_{2} \mathrm{O}$ ). The aniline derivative was extracted with diethyl ether, dried over $\mathrm{MgSO}_{4}$ and evaporated under reduced pressure to afford aniline 10 (5.86 g, 89\% crude yield) as a colourless solid. To a suspension of crude aniline $10(5.82 \mathrm{~g}, 17 \mathrm{mmol})$ in $\mathrm{CHCl}_{3}$ (35 mL) were added $\mathrm{NaHCO}_{3}\left(1.5 \mathrm{M}\right.$ in $\left.\mathrm{H}_{2} \mathrm{O}\right)(30 \mathrm{~mL}, 50 \mathrm{mmol}), \mathrm{NaCl}(2.95 \mathrm{~g}, 50$ $\mathrm{mmol})$ and di-tert-butyl dicarbonate $\left(\mathrm{BOC}_{2} \mathrm{O}\right)(9.6 \mathrm{~mL}, 42 \mathrm{mmol})$. The reaction mixture was refluxed for $48 \mathrm{~h}$. The reaction was quenched by addition of water and the crude product was extracted with $\mathrm{CH}_{2} \mathrm{Cl}_{2}$ (DCM). The organic phase was washed with brine, dried over $\mathrm{MgSO}_{4}$ and evaporated under reduced pressure. Purification by flash chromatography (hexanes/EtOAc, 95: 5) afforded a mixture of two products: the

${ }^{1}$ See reference 14 
desired aniline 11 and $\mathrm{BOC}_{2} \mathrm{O}$. Recrystallization from $\mathrm{EtOH}$ and $\mathrm{H}_{2} \mathrm{O}$ gained the aniline 11 (5.27 g, 71\% yield) as a white solid. IR (film) $v=3328(\mathrm{~N}-\mathrm{H}$, carbamate), $1700\left(\mathrm{C}=\mathrm{O}\right.$, carbamate) ${ }^{1} \mathrm{H}$ NMR $\left(400 \mathrm{MHz}\right.$, acetone- $\left.\mathrm{d}_{6}\right) \delta=1.49\left(\mathrm{~s}, 9 \mathrm{H},\left(\mathrm{CH}_{3}\right)_{3} \mathrm{C}\right.$ of N-BOC), 7.73 (t, $J=1.4 \mathrm{~Hz}, 1 \mathrm{H}, 4-\mathrm{CH}), 8.04(\mathrm{~d}, J=1.2 \mathrm{~Hz}, 2 \mathrm{H}, 2-\mathrm{CH}), 8.65(\mathrm{~s}, 1 \mathrm{H}$, $\mathrm{NH}) ;{ }^{13} \mathrm{C}$ NMR (75 MHz, acetone- $\left.\mathrm{d}_{6}\right) \delta=28.4(3 \mathrm{x}), 81.0,95.1(2 \mathrm{x}), 126.9(2 \mathrm{x})$, 139.2, 143.1, 153.2; LRMS: calculated for $\mathrm{C}_{11} \mathrm{H}_{14} \mathrm{I}_{2} \mathrm{NO}_{2}[\mathrm{M}+\mathrm{H}]^{+} 445.9$, found 445.5 $\mathrm{m} / \mathrm{z}$.

Synthesis of N-tert-butoxycarbonyl-3-iodo-5-(2'-propenyl)-aniline (12)

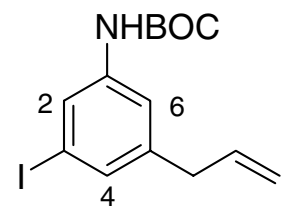

To a solution of $11(6.00 \mathrm{~g}, 13.5 \mathrm{mmol})$ in dry THF $(130 \mathrm{~mL})$ under argon atmosphere at $-20^{\circ} \mathrm{C}$ was added isopropylmagnesium chloride (iPrMgCl) $(2.0 \mathrm{M}$ in THF) $(14.8 \mathrm{~mL}, 30 \mathrm{mmol})$. The mixture was stirred for $30 \mathrm{~min}$ at $-20^{\circ} \mathrm{C}$. Then, a solution of $\mathrm{CuCN}(1.44 \mathrm{~g}, 16.1 \mathrm{mmol})$ and dry $\mathrm{LiCl}(1.36 \mathrm{~g}, 32.3 \mathrm{mmol})$ in dry THF $(16 \mathrm{~mL})$ was added and stirred for $20 \mathrm{~min}$. Allyl bromide $(3.35 \mathrm{~mL}, 40 \mathrm{mmol})$ was added slowly to the reaction mixture and allowed to stir and warm to room temperature for $1 \mathrm{~h}$. The reaction was quenched by addition of a saturated $\mathrm{NH}_{4} \mathrm{Cl}$ solution and extraction was performed with EtOAc. The organic layer was washed with brine, dried over $\mathrm{MgSO}_{4}$ and evaporated to dryness. The crude residue was purified by chromatography (hexanes/EtOAc, 95: 5) to afford $\mathbf{1 2}$ (4.72 g, 98\% yield) as a white solid. IR (film) $v=3329\left(\mathrm{NH}\right.$, carbamate), $1700\left(\mathrm{C}=\mathrm{O}\right.$, carbamate); ${ }^{1} \mathrm{H}$ NMR (400 MHz, acetone-d $\left.\mathrm{d}_{6}\right) \delta=1.49\left(\mathrm{~s}, 9 \mathrm{H},\left(\mathrm{CH}_{3}\right)_{3} \mathrm{C}\right.$ of N-BOC), $3.33(\mathrm{~d}, J=6.8$ $\left.\mathrm{Hz}, 2 \mathrm{H},-\mathrm{C}_{2}-\mathrm{CH}=\mathrm{CH}_{2}\right), 5.10\left(\mathrm{~m}, 2 \mathrm{H},-\mathrm{CH}_{2}-\mathrm{CH}=\mathrm{CH}_{2}\right), 5.95\left(\mathrm{~m}, 1 \mathrm{H},-\mathrm{CH}_{2}-\mathrm{C} \underline{\mathrm{H}}=\mathrm{CH}_{2}\right)$, $7.23(\mathrm{~d}, J=1.2 \mathrm{~Hz}, 1 \mathrm{H}, 4-\mathrm{CH}), 7.39(\mathrm{~s}, 1 \mathrm{H}, 6-\mathrm{CH}), 7.93(\mathrm{~s}, 1 \mathrm{H}, 2-\mathrm{CH}), 8.50(\mathrm{~s}, 1 \mathrm{H}$, $\mathrm{NH}) ;{ }^{13} \mathrm{C}$ NMR $\left(75 \mathrm{MHz}\right.$, acetone- $\left.\mathrm{d}_{6}\right) \delta=28.4(3 \mathrm{x}), 40.2,80.4,94.6,116.6,118.5$, 125.3, 132.0, 137.8, 142.0, 144.0, 153.5; LRMS: calculated for $\mathrm{C}_{14} \mathrm{H}_{17} \mathrm{INO}_{2}[\mathrm{M}-\mathrm{H}]^{-}$ 358.0 , found $357.9 \mathrm{~m} / \mathrm{z}$. 
Synthesis of methyl 2-(3'-tert-butoxycarbonylamino-5'-iodophenyl) acetate (4)

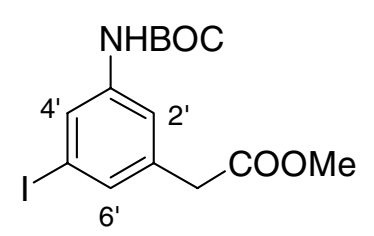

Compound 12 (4.63 g, $12.9 \mathrm{mmol})$ was dissolved in $\mathrm{CCl}_{4}(100 \mathrm{~mL}), \mathrm{CH}_{3} \mathrm{CN}$ (100 $\mathrm{mL})$ and $\mathrm{H}_{2} \mathrm{O}(150 \mathrm{~mL}) . \mathrm{NaIO}_{4}(13.78 \mathrm{~g}, 64.4 \mathrm{mmol})$ and $\mathrm{RuCl}_{3} \cdot \mathrm{H}_{2} \mathrm{O}(400 \mathrm{mg}, 1.9 \mathrm{mmol})$ were added and the reaction mixture was stirred for $10 \mathrm{~min}$ at room temperature. Then, the mixture was poured into water and extracted with DCM. The organic phase was washed with brine, dried over $\mathrm{MgSO}_{4}$ and evaporated under reduced pressure. The crude acid was dissolved in $\mathrm{MeOH}(100 \mathrm{~mL})$ and cooled at $0^{\circ} \mathrm{C}$. $\mathrm{TMSCHN}_{2}(2.0 \mathrm{M}$ in hexanes) $(38 \mathrm{~mL}, 76 \mathrm{mmol}$ ) was added slowly and the mixture was allowed to stir for $10 \mathrm{~min}$ at $0^{\circ} \mathrm{C}$. Then, $\mathrm{MeOH}$ was removed under reduced pressure. The crude product was purified by flash chromatography (hexanes/EtOAc, 9: 1) and yielded 4 (3.4 g, 68\% yield for two steps) as a white solid. IR (film) $v=3336(\mathrm{NH}$, carbamate), $1726(\mathrm{C}=\mathrm{O}$, ester and carbamate); ${ }^{1} \mathrm{H}$ NMR (300 MHz, acetone- $\left.\mathrm{d}_{6}\right) \delta=1.50\left(\mathrm{~s}, 9 \mathrm{H},\left(\mathrm{CH}_{3}\right)_{3} \mathrm{C}\right.$ of N-BOC), 3.63 (s, $\left.2 \mathrm{H}, \mathrm{C}_{2} \mathrm{COOCH}_{3}\right), 3.67$ (s, $\left.3 \mathrm{H}, \mathrm{COOC}_{3}\right), 7.34$ (s, $1 \mathrm{H}, 6$ ' $\left.-\mathrm{CH}\right), 7.49$ (s, $\left.1 \mathrm{H}, 2^{\prime}-\mathrm{CH}\right)$, $7.99\left(\mathrm{~s}, 1 \mathrm{H}, 4^{\prime}-\mathrm{CH}\right), 8.56(\mathrm{~s}, 1 \mathrm{H}, \mathrm{NH}) ;{ }^{13} \mathrm{C}$ NMR $\left(75 \mathrm{MHz}\right.$, acetone- $\left.\mathrm{d}_{6}\right) \delta=28.2(3 \mathrm{x})$, 40.5, 52.0, 80.3 , 94.2, 119.2, 125.8, 132.6, 138.0, 141.8, 153.2, 171.5; LRMS: calculated for $\mathrm{C}_{14} \mathrm{H}_{17} \mathrm{INO}_{4}[\mathrm{M}-\mathrm{H}]^{-} 390.0$, found $389.9 \mathrm{~m} / \mathrm{z}$.

Synthesis of 10-undecenal (8)

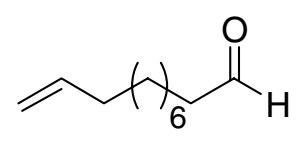

Molecular sieves (7.3 g) and 4-methylmorpholine N-oxide (NMO) (2.56 g, 21.9 $\mathrm{mmol})$ were added to a solution of alcohol $13(2.5 \mathrm{~g}, 14.6 \mathrm{mmol})$ in dry DCM $(150 \mathrm{~mL})$ under argon atmosphere at room temperature. The reaction mixture was stirred for 15 min. Then, tetrapropylammonium perruthenate (TPAP) $(250 \mathrm{mg}, 0.71 \mathrm{mmol})$ was added and the mixture was stirred for $1 \mathrm{~h}$. DCM was removed under reduced pressure and the aldehyde was purified by flash chromatography (hexanes/EtOAc, 95: 5) to yield aldehyde $8(2.3 \mathrm{~g}, 94 \%$ yield $)$ as a colourless oil. IR (film) $v=3076(\mathrm{C}-\mathrm{H}$, alkene), $2713(\mathrm{C}-\mathrm{H}$, aldehyde), $1727\left(\mathrm{C}=\mathrm{O}\right.$, aldehyde), $1640\left(\mathrm{C}=\mathrm{C}\right.$, alkene); ${ }^{1} \mathrm{H} \mathrm{NMR}\left(400 \mathrm{MHz}, \mathrm{CDCl}_{3}\right) \delta=$ $1.29\left(\mathrm{~m}, 10 \mathrm{H}, \mathrm{CH}_{2}\right), 1.62\left(\mathrm{~m}, 2 \mathrm{H}, \mathrm{C}_{2} \mathrm{CH}_{2} \mathrm{CHO}\right.$ ), 2.03 (m, 2H, $\mathrm{CH}_{2} \mathrm{CH}=\mathrm{CH}_{2}$ ), 2.41 (dt, $\left.J_{I}=7.4 \mathrm{~Hz}, J_{2}=1.8 \mathrm{~Hz}, 2 \mathrm{H}, \mathrm{CH}_{2} \mathrm{CHO}\right), 4.95\left(\mathrm{~m}, 2 \mathrm{H}, \mathrm{CH}=\mathrm{CH}_{2}\right), 5.80\left(\mathrm{~m}, 1 \mathrm{H}, \mathrm{CH}=\mathrm{CH}_{2}\right)$, $9.75(\mathrm{t}, J=1.8 \mathrm{~Hz}, 1 \mathrm{H}, \mathrm{CHO}) ;{ }^{13} \mathrm{C}$ NMR $\left(75 \mathrm{MHz}, \mathrm{CDCl}_{3}\right) \delta=22.0,28.8,29.0,29.1$, $29.18,29.22,33.7,43.8,114.1,139.0,202.8$. 
Synthesis of 13-[3'-(tert-butyldimethylsilyloxy)-17' $\beta$-(tetrahydro-2H-pyran-2-yl-oxy)estra-1',3',5'(10')-trien-16' $\beta$-yll-tridecyne (6)

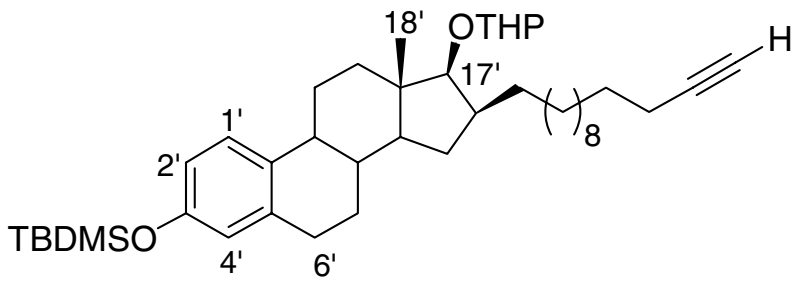

A mixture of protected $16 \beta$-allyl estradiol $7^{2}(4 \mathrm{~g}, 7.8 \mathrm{mmol})$, freshly prepared aldehyde $\mathbf{8}(2.92 \mathrm{~g}, \quad 17.4 \mathrm{mmol})$ and tricyclohexylphosphine [1,3-bis(2,4,6trimethylphenyl)-4,5-dihydroimidazol-2-ylidene] [benzylidine] ruthenium(IV)dichloride (Grubbs's catalyst) $(664 \mathrm{mg}, 0.78 \mathrm{mmol})$ in dry DCM $(130 \mathrm{~mL})$ was refluxed for $16 \mathrm{~h}$ under argon atmosphere. The crude mixture was preabsorbed on silica gel and a flash chromatography was performed with hexanes/EtOAc, 97:3 to 95:5 to afford 3.12 g of a mixture of the desired steroid $\mathbf{1 4}$ (89\% of the mixture) and "self-metathesis steroid product" (11\% of the mixture). Thus, the real yield of $\mathbf{1 4}$ was $55 \%$ as determined after the purification of alkyne $\mathbf{6}$ which allowed the separation of the "self-metathesis steroid product". A suspension of crude steroid 14 (3.12 g) and 10\% Pd/C (468 mg) in EtOAc $(95 \mathrm{~mL})$ was stirred under hydrogen atmosphere at room temperature. After $16 \mathrm{~h}$, the resulting suspension was filtered through celite and EtOAc was evaporated to dryness. ${ }^{1} \mathrm{H}$ analysis of the crude mixture revealed the disappearance of the alkene protons (5.43 ppm). Under an argon atmosphere, a solution of lithium diisopropyl amide (LDA) was prepared at $0^{\circ} \mathrm{C}$ by adding $\mathrm{n}-\mathrm{BuLi}(1.4 \mathrm{M}$ in hexanes) $(3.6 \mathrm{~mL}, 5.1 \mathrm{mmol})$ to a solution of diisopropylamine $(0.71 \mathrm{~mL}, 5.1 \mathrm{mmol})$ in dry THF $(46 \mathrm{~mL})$. After $30 \mathrm{~min}$, the LDA solution was cooled at $-78^{\circ} \mathrm{C}$ and $\mathrm{TMSCHN}_{2}(2.0 \mathrm{M}$ in hexanes) $(2.5 \mathrm{~mL}, 5.1 \mathrm{mmol})$ was added slowly and stirred for $30 \mathrm{~min}$ at $-78^{\circ} \mathrm{C}$. The crude steroid $(3.02 \mathrm{~g})$ dissolved in dry THF (15 mL) was added slowly to the reaction mixture, which was allowed to stir $1 \mathrm{~h}$ at $-78^{\circ} \mathrm{C}$ and then $3 \mathrm{~h}$ at $70^{\circ} \mathrm{C}$. After cooling to room temperature, the reaction was quenched by addition of water and the crude product was extracted with EtOAc. The organic phase was washed with brine, dried $\left(\mathrm{MgSO}_{4}\right)$ and the solvent was removed under vacuum. Purification by flash chromatography (hexanes/EtOAc, 98:2 to 95:5) yielded and allowed to separate the pure alkyne $4(1.56 \mathrm{~g}, 59 \%$ yield for two steps) as colourless viscous oil from the "self-metathesis steroid product" $(0.34 \mathrm{~g})$. IR (film) $v=3313(\mathrm{C}-\mathrm{H}$, alkyne); ${ }^{1} \mathrm{H}$ NMR (400 MHz, acetone- $\left.\mathrm{d}_{6}\right) \delta=0.20\left(\mathrm{~s}, 6 \mathrm{H}, \mathrm{Si}\left(\mathrm{CH}_{3}\right)_{2}\right), 0.82$ and $0.86(2 \mathrm{~s}$, $\left.3 \mathrm{H}, 18^{\prime}-\mathrm{CH}_{3}\right), 0.99$ (s, $\left.9 \mathrm{H}, \mathrm{SiC}\left(\mathrm{CH}_{3}\right)_{3}\right), 1.03$ to 2.30 (m, 38H, $\mathrm{CH}$ and $\mathrm{CH}_{2}$ of steroid skeleton and alkyl chain) 2.18 (dt, $\left.J_{I}=7.0 \mathrm{~Hz}, J_{2}=2.6 \mathrm{~Hz}, 2 \mathrm{H}, \mathrm{CH}_{2}-\mathrm{C} \equiv \mathrm{C}\right), 2.33(\mathrm{t}, J=$ $2.6 \mathrm{~Hz}, 1 \mathrm{H}, \mathrm{C} \equiv \mathrm{C}-\mathrm{H}), 2.80\left(\mathrm{~m}, 2 \mathrm{H}, 6^{\prime}-\mathrm{CH}_{2}\right), 3.47$ and $3.92\left(2 \mathrm{~m}, 2 \mathrm{H}, \mathrm{OCH}_{2}\right.$ of THP), 3.74 and $3.79\left(2 \mathrm{~d}, J=9.7 \mathrm{~Hz}, 1 \mathrm{H}, 17^{\prime} \alpha-\mathrm{CH}\right), 4.63$ and $4.73(2 \mathrm{~m}, 1 \mathrm{H}, \mathrm{CH}$ of THP), $6.58(\mathrm{~d}, J$ $\left.=2.1 \mathrm{~Hz}, 1 \mathrm{H}, 4^{\prime}-\mathrm{CH}\right), 6.63\left(\mathrm{~d}, J=8.4 \mathrm{~Hz}, 1 \mathrm{H}, 2^{\prime}-\mathrm{CH}\right), 7.16\left(2 \mathrm{~d}, J=8.3 \mathrm{~Hz}, 1 \mathrm{H}, 1^{\prime}-\mathrm{CH}\right)$; LRMS: calculated for $\mathrm{C}_{42} \mathrm{H}_{69} \mathrm{O}_{3} \mathrm{Si}[\mathrm{M}+\mathrm{H}]^{+} 649.5$, found $649.4 \mathrm{~m} / \mathrm{z}$.

\footnotetext{
${ }^{2}$ See reference 24
} 
Synthesis of methyl 2-\{3'-(tert-butoxycarbonylamino)-5'-[13'”-(3'"'-(tertbutyldimethylsilyloxy)-17",' $\beta$-(tetrahydro-2H-pyran-2-yl-oxy)-estra-1",',3,",5"' (10"')trien-16"' $\beta$-yl)-tridecynyll-phenyl $\}$-acetate (15)

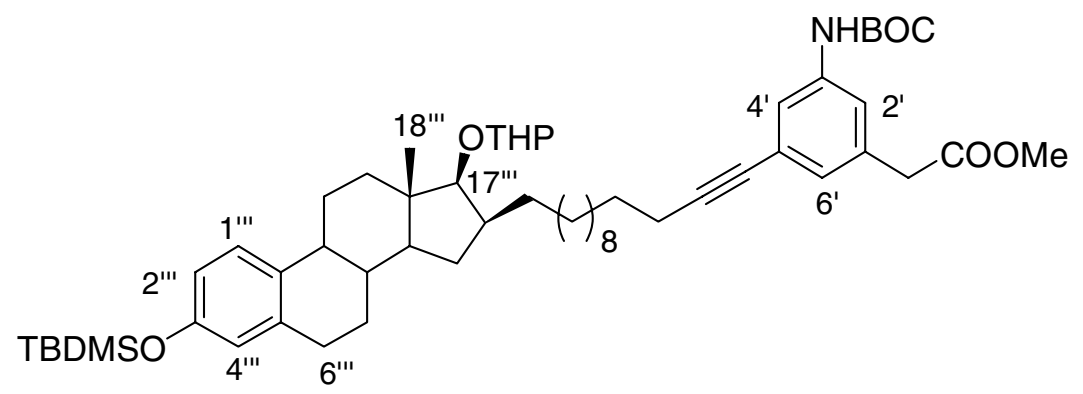

To a solution of alkyne 6 (200 $\mathrm{mg}, 0.32 \mathrm{mmol})$ and cuprous iodide $(25 \mathrm{mg}, 0.13$ $\mathrm{mmol})$ in dry and degassed benzene $(3.5 \mathrm{~mL})$ under argon was added triethylamine $(0.15$ $\mathrm{mL}, 1.00 \mathrm{mmol})$. This mixture was stirred for $10 \mathrm{~min}$ at room temperature, and this was followed by the addition of a mixture of 4 (103 mg, $0.26 \mathrm{mmol})$ and tetrakis(triphenylphosphine)-palladium (30 $\mathrm{mg}, 0.02 \mathrm{mmol}$ ) dissolved in dry and degassed benzene $(0.5 \mathrm{~mL})$ prepared in a separate flask under argon $(20 \mathrm{~min}$, room temperature). The resulting mixture was stirred $3 \mathrm{~h}$ at $40^{\circ} \mathrm{C}$ and poured into a mixture (50/50) of saturated $\mathrm{NaHCO}_{3}$ and $\mathrm{NH}_{4} \mathrm{Cl}$ solution. The crude product was extracted with EtOAc and the organic phase was washed with brine and dried over $\mathrm{MgSO}_{4}$. Purification of the crude compound by flash chromatography (hexanes/EtOAc, 95: 5 to 90: 10) yielded $15(227 \mathrm{mg}, 95 \%$ yield) as a colourless foam. IR (film) $v=3348(\mathrm{NH}$, carbamate), $1734\left(\mathrm{C}=\mathrm{O}\right.$, ester and carbamate); ${ }^{1} \mathrm{H}$ NMR $\left(400 \mathrm{MHz}\right.$, acetone- $\left.\mathrm{d}_{6}\right) \delta=0.21$ (s, 6H, $\left.\mathrm{Si}\left(\mathrm{CH}_{3}\right)_{2}\right), 0.82$ and $0.86\left(2 \mathrm{~s}, 3 \mathrm{H}, 18\right.$ '" $\left.-\mathrm{CH}_{3}\right), 1.00$ (s, $\left.9 \mathrm{H}, \mathrm{SiC}\left(\mathrm{CH}_{3}\right)_{3}\right), 1.04$ to $2.32\left(\mathrm{~m}, 38 \mathrm{H}, \mathrm{CH}\right.$ and $\mathrm{CH}_{2}$ of steroid skeleton and alkyl chain), $1.50\left(\mathrm{~s}, 9 \mathrm{H},\left(\mathrm{CH}_{3}\right)_{3} \mathrm{C}\right.$ of N-BOC), 2.42 (t, $\left.J=6.9 \mathrm{~Hz}, 2 \mathrm{H}, \mathrm{CH}_{2}-\mathrm{C} \equiv \mathrm{C}\right), 2.81\left(\mathrm{~m}, 2 \mathrm{H}, 6{ }^{\prime}{ }^{\prime}-\mathrm{CH}_{2}\right), 3.48$ and $3.92(2 \mathrm{~m}$, $2 \mathrm{H}, \mathrm{OCH}_{2}$ of THP), $3.60\left(\mathrm{~s}, 2 \mathrm{H}, \mathrm{CH}_{2} \mathrm{COOCH}_{3}\right), 3.66$ (s, $\left.3 \mathrm{H}, \mathrm{COOCH}_{3}\right), 3.73$ and 3.78 (2d, $J=9.7 \mathrm{~Hz}, 1 \mathrm{H}, 17$ '" ' $\alpha-\mathrm{CH}), 4.63$ and $4.73(2 \mathrm{~m}, 1 \mathrm{H}, \mathrm{CH}$ of THP), 6.57 (s, $1 \mathrm{H}, 4$ ', '$\mathrm{CH}), 6.63\left(\mathrm{~d}, J=8.4 \mathrm{~Hz}, 1 \mathrm{H}, 2\right.$ '" '-CH), $6.97\left(\mathrm{~s}, 1 \mathrm{H}, 6{ }^{\prime}-\mathrm{CH}\right), 7.15\left(\mathrm{~m}, 1 \mathrm{H}, 1^{\prime \prime}{ }^{\prime}-\mathrm{CH}\right), 7.48$ $\left(\mathrm{s}, 1 \mathrm{H}, 2^{\prime}-\mathrm{CH}\right), 7.58\left(\mathrm{~s}, 1 \mathrm{H}, 4^{\prime}-\mathrm{CH}\right), 8.47(\mathrm{~s}, 1 \mathrm{H}, \mathrm{NH})$; LRMS: calculated for $\mathrm{C}_{56} \mathrm{H}_{84} \mathrm{NO}_{7} \mathrm{Si}[\mathrm{M}-\mathrm{H}]^{-} 910.6$, found $910.5 \mathrm{~m} / \mathrm{z}$. 
Synthesis of methyl 2-\{3'-amino-5'-[13"'-(3'", $17^{\prime \prime \prime \prime} \beta-$ dihydroxy-estra1 ", ,3"',5",'(10"')-trien-16",' $\beta$-yl)-tridecynyll-phenyl $\}$-acetate (the deprotected form of $\underline{15)}$.

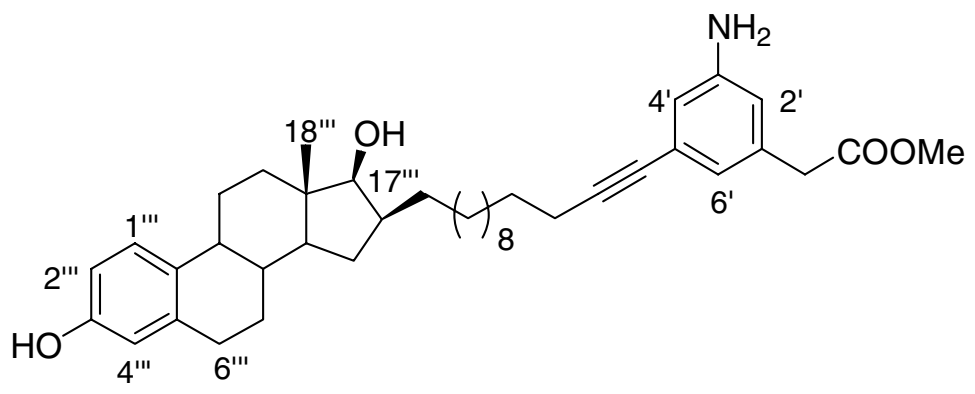

A solution of ester $15(200 \mathrm{mg}, 0.22 \mathrm{mmol})$ in dry DCM $(1.5 \mathrm{~mL})$ and dry $\mathrm{MeOH}$ $(1.5 \mathrm{~mL})$ under argon atmosphere was treated with $\mathrm{HCl}(4 \mathrm{M}$ in dioxane) $(0.22 \mathrm{~mL}, 0.88$ $\mathrm{mmol}$ ). The resulting mixture was stirred at room temperature for $16 \mathrm{~h}$. The reaction was quenched by addition of a saturated $\mathrm{NaHCO}_{3}$ solution and extraction was performed with EtOAc. The organic phase was washed with brine, dried $\left(\mathrm{MgSO}_{4}\right)$ and evaporated to dryness under reduced pressure. To obtain the salt-free product, the crude product$\mathrm{NH}_{2} \cdot \mathrm{HCl}(162 \mathrm{mg})$ was dissolved in $\mathrm{MeOH}(5 \mathrm{~mL})$ and $\mathrm{Cs}_{2} \mathrm{CO}_{3}(400 \mathrm{mg})$ was added. The mixture was stirred $15 \mathrm{~min}$ and the extraction procedure was done as described above. Purification of the crude compound by flash chromatography (hexanes/EtOAc, 7: 3) afforded the desired product ( $125 \mathrm{mg}, 93 \%$ yield) as a colourless solid. IR (film) $v=$ $3372\left(\mathrm{OH}\right.$ and $\left.\mathrm{NH}_{2}\right), 1729\left(\mathrm{C}=\mathrm{O}\right.$, ester); ${ }^{1} \mathrm{H} \mathrm{NMR}\left(400 \mathrm{MHz}\right.$, acetone- $\left.\mathrm{d}_{6}\right) \delta=0.80(\mathrm{~s}, 3 \mathrm{H}$, 18 "' $\left.-\mathrm{CH}_{3}\right), 0.98$ to $2.31\left(\mathrm{~m}, 32 \mathrm{H}, \mathrm{CH}\right.$ and $\mathrm{CH}_{2}$ of steroid skeleton and alkyl chain), 2.38 (t, $\left.J=7.0 \mathrm{~Hz}, 2 \mathrm{H}, \mathrm{CH}_{2}-\mathrm{C} \equiv \mathrm{C}\right), 2.79\left(\mathrm{~m}, 2 \mathrm{H}, 6\right.$ '" $\left.-\mathrm{CH}_{2}\right), 3.46\left(\mathrm{~s}, 2 \mathrm{H}, \mathrm{CH}_{2} \mathrm{COOCH}_{3}\right), 3.54$ $\left(\mathrm{d}, J=5.4 \mathrm{~Hz}, 1 \mathrm{H}, 17^{\prime \prime}, \beta-\mathrm{OH}\right), 3.64\left(\mathrm{~s}, 3 \mathrm{H}, \mathrm{COOCH}_{3}\right), 3.73\left(\mathrm{dd}, J_{l}=9.7 \mathrm{~Hz}, J_{2}=5.4\right.$ $\mathrm{Hz}, 1 \mathrm{H}, 17$ ' ' $\alpha-\mathrm{CH}), 4.73$ (s, 2H, NH${ }_{2}$ ), 6.58 (m, 5H, 2'-CH, 4'-CH, 6'-CH, 2'"'-CH and 4" '-CH), $7.10(\mathrm{~d}, J=8.4 \mathrm{~Hz}, 1 \mathrm{H}, 1$,"'-CH), 7.96 (s, 1H, 3'"'-OH); LRMS: calculated for $\mathrm{C}_{40} \mathrm{H}_{54} \mathrm{NO}_{4}[\mathrm{M}-\mathrm{H}]^{-} 612.4$, found $612.6 \mathrm{~m} / \mathrm{z}$. 
Synthesis of methyl 2-\{3'-amino-5'-[13''-(3',', 17', $\beta$ - dihydroxy-estra-

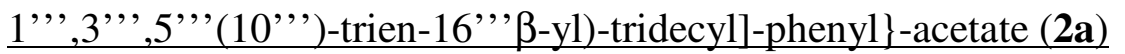

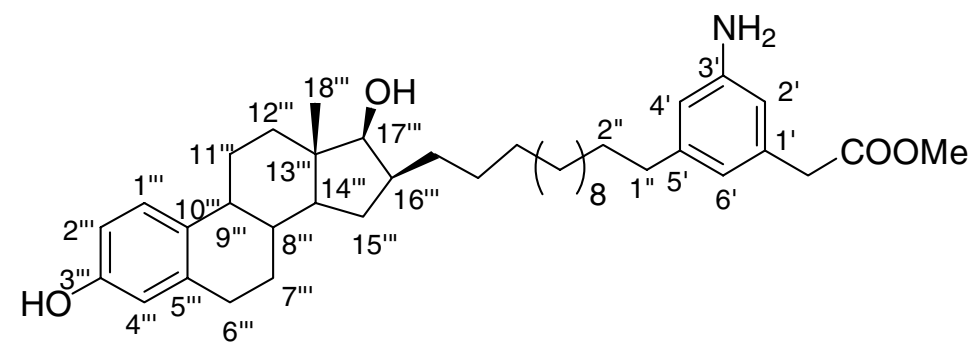

To a solution of the deprotected form of alkyne 15 (162 mg, $0.26 \mathrm{mmol})$ in EtOAc (5 $\mathrm{mL}$ ) was added $10 \% \mathrm{Pd} / \mathrm{C}(32 \mathrm{mg})$. This mixture was stirred $16 \mathrm{~h}$ under hydrogen atmosphere at room temperature. The resulting suspension was filtered through celite and EtOAc was evaporated to dryness. The crude compound was purified by flash chromatography (hexanes/EtOAc, 7: 3), which yielded the ester 2a (115 mg, 71\% yield) as white foam. IR (film) $v=3375\left(\mathrm{OH}\right.$ and $\left.\mathrm{NH}_{2}\right), 1732\left(\mathrm{C}=\mathrm{O}\right.$, ester); ${ }^{1} \mathrm{H}$ NMR (400 $\mathrm{MHz}$, acetone- $\left.\mathrm{d}_{6}\right) \delta=0.80$ (s, $\left.3 \mathrm{H}, 18^{\prime \prime}{ }^{-} \mathrm{CH}_{3}\right), 0.98$ to 2.31 (m, $36 \mathrm{H}, \mathrm{CH}$ and $\mathrm{CH}_{2}$ of steroid skeleton and alkyl chain), 2.45 (t, $J=7.8 \mathrm{~Hz}, 2 \mathrm{H}, 1$ '"- $\left.\mathrm{CH}_{2}\right), 2.78(\mathrm{~m}, 2 \mathrm{H}, 6$,"'$\left.\mathrm{CH}_{2}\right), 3.44\left(\mathrm{~s}, 2 \mathrm{H}, \mathrm{C}_{2} \mathrm{COOCH}_{3}\right), 3.55\left(\mathrm{~d}, J=5.4 \mathrm{~Hz}, 1 \mathrm{H}, 17^{\prime \prime}, \beta-\mathrm{OH}\right), 3.62(\mathrm{~s}, 3 \mathrm{H}$, $\left.\mathrm{COOCH}_{3}\right), 3.73\left(\mathrm{dd}, J_{1}=9.7 \mathrm{~Hz}, J_{2}=5.5 \mathrm{~Hz}, 1 \mathrm{H}, 17^{\prime}{ }^{\prime \prime} \alpha-\mathrm{CH}\right), 4.54\left(\mathrm{~s}, 2 \mathrm{H}, \mathrm{NH}_{2}\right), 6.37$ (s, $1 \mathrm{H}, 6$ ' $-\mathrm{CH}), 6.42$ (s, 2H, 2'-CH and 4'-CH), 6.54 (d, $J=1.8 \mathrm{~Hz}, 1 \mathrm{H}, 4$ '"' $-\mathrm{CH}), 6.60$ (dd, $J_{I}=8.4 \mathrm{~Hz}, J_{2}=2.4 \mathrm{~Hz}, 1 \mathrm{H}, 2$," $\left.-\mathrm{CH}\right), 7.10\left(\mathrm{~d}, J=8.4 \mathrm{~Hz}, 1 \mathrm{H}, 1,{ }^{\prime}{ }^{-\mathrm{CH}}\right), 7.97(\mathrm{~s}, 1 \mathrm{H}$, 3 "',-OH); ${ }^{13} \mathrm{C}$ NMR (100 MHz, acetone-d $\left.\mathrm{d}_{6}\right) \delta^{3}=13.0$ (C18'"'), 27.2 (C11'"'), 28.3 (C7"'), 29.2 to 30.3 (C6"' and C'"on alkyl chain: under solvent peaks), 30.7 (C2"), 32.1 (C15"'), 32.6 and 33.3 (C'"on alkyl chain), 36.3 (C1"'), 38.7 (C12'"'), 39.5 (C8"'), 41.2 $\left(\mathrm{CH}_{2} \mathrm{COOCH}_{3}\right), 41.3$ (C16"'), 44.88 (C13"'), 44.92 (C9"'), 49.5 (C14"'), 51.9 $\left(\mathrm{COOCH}_{3}\right), 82.3\left(\mathrm{C} 17\right.$ '”'), 113.5 (C2'"'), $115.9\left(\mathrm{C} 4{ }^{\prime \prime} '\right), 118.4$ and $118.7(\mathrm{C} 2$ ' and $\mathrm{C} 4$ '), 124.5 (C6'), 126.9 (C1'"'), 132.1 (C10'”), 135.8 (C1'), 138.4 (C5'"'), 144.4 (C5'), 152.9 (C3'), $155.8\left(\mathrm{C} 3\right.$ '"), $172.2\left(\mathrm{COOCH}_{3}\right)$; LRMS: calculated for $\mathrm{C}_{40} \mathrm{H}_{60} \mathrm{NO}_{4}[\mathrm{M}+\mathrm{H}]^{+}$618.4, found $618.2 \mathrm{~m} / \mathrm{z}$.

\footnotetext{
${ }^{3}$ Complete assignation of ${ }^{13} \mathrm{C}$ NMR of compound 2a was done using 2D NMR (HSQC, HMBC and COSY experiments) and published ${ }^{13} \mathrm{C}$ NMR data on estradiol derivatives, see Dionne, P.; Ngatcha, B.T.; Poirier, D. Steroids 1997, 62, 674-681.
} 
Synthesis of 3-amino-5-[13'-(3', 17' $\beta$ - dihydroxy-estra-1', ,3', ,5' (10',)-trien-16' $\beta$-yl)tridecyll-phenylacetic acid (2b)

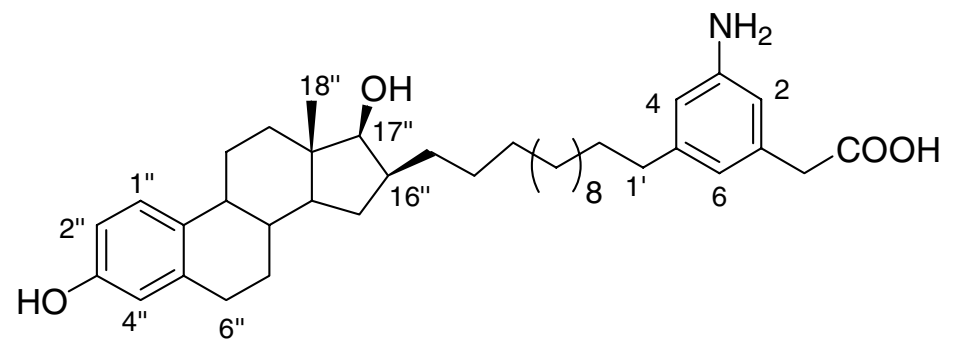

Ester $2 \mathbf{a}(32 \mathrm{mg}, 0.052 \mathrm{mmol})$ was dissolved in THF $(0.6 \mathrm{~mL})$ and a solution of $\mathrm{HCl}$ $\left(1 \mathrm{~N}\right.$ in $\mathrm{H}_{2} \mathrm{O}, 0.6 \mathrm{~mL}$ ) was added. The resulting mixture was refluxed for $5 \mathrm{~h}$. The reaction was quenched by addition of a saturated $\mathrm{NaHCO}_{3}$ solution and extraction was performed with EtOAc. The organic phase was washed with brine, dried $\left(\mathrm{MgSO}_{4}\right)$ and evaporated to dryness under reduced pressure. Purification by flash chromatography (MeOH/DCM, 5: 95 to 10: 90) afforded $\mathbf{2 b}(18 \mathrm{mg}, 58 \%)$ as white foam. IR (film) $\mathrm{v}=3600-2300(\mathrm{OH}$, carboxylic acid), 3434 and $3380\left(\mathrm{OH}\right.$ and $\left.\mathrm{NH}_{2}\right), 1706(\mathrm{C}=\mathrm{O}$, carboxylic acid $) ;{ }^{1} \mathrm{H} \mathrm{NMR}$ (400 MHz, acetone- $\mathrm{d}_{6}$ and methanol- $\left.\mathrm{d}_{4}\right) \delta=0.80\left(\mathrm{~s}, 3 \mathrm{H}, 18{ }^{\prime}{ }^{-}-\mathrm{CH}_{3}\right), 0.82$ to $2.32(\mathrm{~m}, 36 \mathrm{H}$, $\mathrm{CH}$ and $\mathrm{CH}_{2}$ of steroid skeleton and alkyl chain), $2.46\left(\mathrm{t}, \mathrm{J}=7.7 \mathrm{~Hz}, 2 \mathrm{H}, 1{ }^{\prime}-\mathrm{CH}_{2}\right), 2.79$ (m, 2H, 6' $-\mathrm{CH}_{2}$ ), 3.42 (s, 2H, $\left.\underline{\mathrm{H}}_{2} \mathrm{COOH}\right), 3.73$ (d, J=9.8 Hz, 1H, 17' ' $\left.\alpha-\mathrm{CH}\right), 6.41$ (m, $2 \mathrm{H}, 2-\mathrm{CH}$ and 4-CH), 6.45 (s, 1H, 6-CH), $6.54(\mathrm{~d}, J=2.4 \mathrm{~Hz}, 1 \mathrm{H}, 4$ ' ' $-\mathrm{CH}), 6.60$ (dd, $J_{1}=$ $8.4 \mathrm{~Hz}, J_{2}=2.6 \mathrm{~Hz}, 1 \mathrm{H}, 2$ ' ' $\left.-\mathrm{CH}\right), 7.10\left(\mathrm{~d}, J=8.5 \mathrm{~Hz}, 1 \mathrm{H}, 1\right.$ ' $\left.{ }^{-\mathrm{CH}}\right) ;{ }^{13} \mathrm{C}$ NMR $(75 \mathrm{MHz}$, acetone- $\mathrm{d}_{6}$ and methanol- $\left.\mathrm{d}_{4}\right) \delta=12.4,26.5,27.6,28.3$ to 29.9 (11C under solvent peaks), 31.5, 32.0, 32.6, 35.9, 38.0, 38.8, 39.6, 41.2, 44.2, 44.3, 47.2, 81.5, 112.7, 115.1, 118.1, 118.3, 124.2, 126.3, 131.4, 135.2, 137.7, 143.6, 148.4, 155.1, 173.5; LRMS: calculated for $\mathrm{C}_{39} \mathrm{H}_{58} \mathrm{NO}_{4}[\mathrm{M}+\mathrm{H}]^{+} 604.4$, found $604.3 \mathrm{~m} / \mathrm{z}$.

Synthesis of 3-amino-5-[13'-(3', 17' $\beta$ - dihydroxy-estra-1', ,3', 5', (10', )-trien-16' $\beta$-yl)tridecyll-phenethyl alcohol (2c)

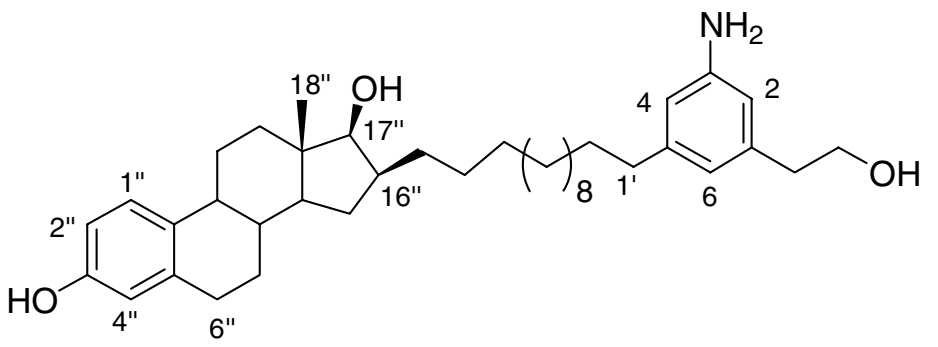


To a solution of ester 2a $(51 \mathrm{mg}, 0.083 \mathrm{mmol})$ in dry THF $(1.7 \mathrm{~mL})$ at $0^{\circ} \mathrm{C}$ under argon atmosphere was added $\mathrm{LiAlH}_{4}(7 \mathrm{mg}, 0.166 \mathrm{mmol})$. The mixture was stirred $16 \mathrm{~h}$ at $0^{\circ} \mathrm{C}$ and quenched by addition of water and $10 \%$ aqueous $\mathrm{NaOH}$. The crude compound was extracted with EtOAc, washed with brine and dried over $\mathrm{MgSO}_{4}$. Purification by flash chromatography (hexanes/EtOAc, 5: 5) yielded 2c (42 $\mathrm{mg}, 87 \%)$ as a white foam. IR (film) $v=3364\left(\mathrm{OH}\right.$ and $\left.\mathrm{NH}_{2}\right) ;{ }^{1} \mathrm{H}$ NMR $\left(400 \mathrm{MHz}\right.$, acetone-d $\left.\mathrm{d}_{6}\right) \delta=0.80(\mathrm{~s}, 3 \mathrm{H}, 18$ '”$\mathrm{CH}_{3}$ ), 0.88 to 2.30 (m, $36 \mathrm{H}, \mathrm{CH}$ and $\mathrm{CH}_{2}$ of steroid skeleton and alkyl chain), 2.44 (t, $J=$ $7.7 \mathrm{~Hz}, 2 \mathrm{H}, 1$ ' $-\mathrm{CH}), 2.66$ (t, $\left.J=7.2 \mathrm{~Hz}, 2 \mathrm{H}, \mathrm{C}_{2} \mathrm{CH}_{2} \mathrm{OH}\right), 2.77\left(\mathrm{~m}, 2 \mathrm{H}, 6\right.$ ' '- $\left.\mathrm{CH}_{2}\right), 3.59$ (m, $2 \mathrm{H}, 17$ ' ' $\beta-\mathrm{OH}$ and $\mathrm{CH}_{2} \mathrm{OH}$ ), $3.71\left(\mathrm{~m}, 3 \mathrm{H}, 17^{\prime} ' \alpha-\mathrm{CH}\right.$ and $\left.\mathrm{C}_{2} \mathrm{OH}\right), 4.42\left(\mathrm{~s}, 2 \mathrm{H}, \mathrm{NH}_{2}\right)$, $6.33(\mathrm{~s}, 1 \mathrm{H}, 6-\mathrm{CH}), 6.36(\mathrm{~s}, 2 \mathrm{H}, 2-\mathrm{CH}$ and $4-\mathrm{CH}), 6.54(\mathrm{~d}, J=2.4 \mathrm{~Hz}, 1 \mathrm{H}, 4$ ' '-CH), 6.60 (dd, $J_{1}=8.4 \mathrm{~Hz}, J_{2}=2.6 \mathrm{~Hz}, 1 \mathrm{H}, 2$ ''-CH), $7.10(\mathrm{~d}, J=8.4 \mathrm{~Hz}, 1 \mathrm{H}, 1$ ' '-CH), $7.99(\mathrm{~s}, 1 \mathrm{H}$, 3 ' $-\mathrm{OH}$ ); ${ }^{13} \mathrm{C}$ NMR $\left(75 \mathrm{MHz}\right.$, acetone- $\mathrm{d}_{6}$ ) $\delta=12.9,27.0,28.1,28.8$ to 30.4 (10C under solvent peaks), 30.5, 32.1, 32.5, 33.1, 36.3, 36.4, 38.5, 39.3, 40.1, 41.1, 44.7, 49.3, 63.9, 82.1, 113.2, 115.7, 118.0, 118.5, 124.2, 126.7, 131.9, 138.1, 140.6, 143.9, 152.4, 155.7; LRMS: calculated for $\mathrm{C}_{39} \mathrm{H}_{60} \mathrm{NO}_{3}[\mathrm{M}+\mathrm{H}]^{+} 590.5$, found $590.4 \mathrm{~m} / \mathrm{z}$. 